\title{
Product regulations and persistence of profits: OECD evidence
}

\author{
Johan E. Eklund ${ }^{1,2,3} \cdot$ Emma Lappi ${ }^{1,3}$
}

Published online: 5 September 2018

(c) The Author(s) 2018

\begin{abstract}
In competitive markets, profits deviating from the norm will not persist for extended periods. If unimpeded, entry and exit of firms should restore profits to competitive levels. This dynamic process is influenced by regulations that temporarily or permanently impede competition. We study how product market regulations (PMR) - as measured by the OECD—affect competition by their impact on the profit persistence (Wölfl et al. in Ten years of product market reform in OECD countries-insights from a revised PMR indicator, 2009, Product market regulation: extending the analysis beyond OECD countries, 2010). To examine profit dynamics, we follow the methodology developed by Mueller (Economica 44(176):369-380, 1977), which measures both the short run persistence of profits and the long run permanent rents. The method can be used to measure: (1) short run transitory rents; (2) long run permanent rents. To this end we use firm level data from 30 OECD countries over the period 1998-2013. Results show that PMR increase the permanent rents of firms but we find no significant effect on short run profit persistence. We conclude that PMR negatively influence competition and increase permanent rents, resulting in misallocation of resources.
\end{abstract}

Keywords Profits · Persistence of profits · Competition · Product market regulation · Regulations · Entry

JEL Classification L12 · L22 · L43 · L50

\footnotetext{
Johan E. Eklund

johan.eklund@entreprenorskapsforum.se

Emma Lappi

emma.lappi@entreprenorskapsforum.se

1 Swedish Entrepreneurship Forum, Grevgatan 34, 3rd floor, Stockholm 114 53, Sweden

2 Blekinge Institute of Technology, Karlskrona, Sweden

3 Jönköping International Business School, Jönköping, Sweden
} 


\section{Introduction}

Regulations aim to modify the behavior of economic agents. Their purpose may be to correct market failures, or they may aim at achieving some distributive goal. Going back to Pigou (1938), for example, regulations were assumed to increase social efficiency by alleviating market failures. In contrast to this public interest theory of regulations, Stigler (1971), Posner (1974) and Peltzman (1976) have put forward public choice theories of regulations. The latter theories hold that regulations favor special interests and are not in the public interest. The debate on the impact of government regulations is by no means a new topic either to policy makers or among scholars. Especially for empirical research, the issue historically has been how to quantify regulations in a meaningful manner. Recent developments in measuring regulations have increased the empirical research in the area. ${ }^{1}$

Much emphasis, both theoretical and empirical, has been put on the regulations in product and factor markets and how they impact the labor market e.g. Salvanes (1997), Blanchard and Giavazzi (2003), Bassanini and Duval (2006) and Feldmann (2012). Also as Kessing (2006) shows theoretically that regulation such as employment protection has important implications for product market competition. More recent research has focused on how regulations - and entry regulations in particular-influence entrepreneurship, innovation, investment, productivity and the economy at large. ${ }^{2}$ Regulations in general are shown to influence economic growth and productivity, e.g. by Dawson (2007), Loayza et al. (2004), Arnold et al. (2011), Bourlès et al. (2013), and Cette et al. (2016). ${ }^{3}$ They show that reallocation of resources towards the most productive firms is stronger in countries where the regulatory burdens are lighter and that anticompetitive upstream regulations have curbed productivity growth, especially in countries that are innovation-driven and close to the productivity frontier.

There is a large amount of empirical evidence on product market regulations and various economic outcomes, other than productivity, labor markets and overall economic performance. Others have looked at the relationship between regulations and investments. For example, Alesina et al. (2005) find that strict government regulation on entry deters investment for OECD countries, and Escribá-Pérez and Murgui-García (2016) find that barriers to entrepreneurship and to trade and investment decrease the productivity of capital, which in turn effects regional investments negatively. ${ }^{4}$ Amable et al. (2009) look at product market regulations and innovation at different distances to the technological frontier. Griffith et al. (2010) find that the EU Single Market Program resulted in increased innovation. ${ }^{5}$ Djankov et al. (2002) record the entry costs associ-

\footnotetext{
1 The most commonly used databases for regulations are the OECD product market regulation indicators, the Frasier Institute index of economic freedom and the World Banks "Doing Business" index.

2 This line of research can be traced back to Hernando de Sotos groundbreaking work in the $1980 \mathrm{~s}$ (de Soto 1989).

${ }^{3}$ See Schiantarelli (2005) for a review of the literature on product market regulation and macroeconomic performance for cross-country studies.

${ }^{4}$ They also find that labor market regulations increase the productivity of capital which then on has a positive effect on regional investment, and that corruption deters investment.

5 The reforms also led to increase in productivity growth and more competition, measured as average profitability.
} 
ated with starting a business in 85 countries and find that entry regulations in particular are detrimental to entrepreneurship, a result also found by Klapper et al. (2006). The empirical findings in the area conclude that entry regulation across countries affects opportunity-driven and formal entrepreneurial outcomes negatively (Klapper et al. 2006). Furthermore, tax regulations, for example, impose administrative burdens on entrepreneurs, which reduce the entry rate (Braunerhjelm and Eklund 2014).

There is also evidence found in favor for enhanced performance and increased trade. Melitz and Ottaviano (2008) build a model where market size and trade liberalization affect product market competition. Lileeva and Trefler (2010) find that improved access to foreign markets in Canada resulted in greater product innovation and technology adaptation, in addition to increased productivity and export activities. Some, such as MacDonald (1994), find that both productivity and productivity growth is positively affected by trade liberalization.

Nicoletti and Scarpetta (2003) conclude that one likely mechanism trough which regulations influence productivity is through competition. Regulations may both promote and impede competition, which in turn will influence the macro- and micro-level outcomes. ${ }^{6}$ The question of how overall product market regulations and the different sub-components of regulation affect economic competition-measured as the persistence of profits above the norm-is an important research topic. According to Geroski and Jacquemin (1988), differences in the strength of antitrust policies and countryspecific regulatory systems could be one explanation of the variation in the speed of profit convergence across countries. This article contributes to the literature by examining the link between product market regulations and the persistence of profit. Despite a relatively large body of literature on the persistence of profits few studies examine the determinants of profit persistence and even fewer do so in a cross-country context. We extend the literature by both looking at the determinants of profit persistence and doing so for a large number of OECD countries.

The profit persistence literature goes back to a seminal contribution by Mueller (1977). A central finding in the literature is that profits above or below the norm tend to persist over time, thus rejecting the hypothesis of perfectly competitive markets (e.g. Mueller 1977; Mueller and Cubbin 2005). Therefore, profits above the norm tend to persist.

To our knowledge, the issue of whether product market regulations affect profit dynamics has been largely neglected in the literature. Griffith et al. (2010) provide empirical evidence on the reduction of regulation and its association with increased product market competition, measured as average profitability, increased innovation intensity and productivity growth for manufacturing sectors across 9 European Union countries. Many have provided evidence that competition is beneficial through increased innovation, efficiency, investments and employment, e.g. Bouis and Duval (2011), Conway et al. (2005, 2006) and Nicoletti and Scarpetta (2003), but regulation and its impact on profit dynamics has not received much attention.

\footnotetext{
6 The dynamic efficiency improvements can be explained in four ways as discussed by Nicoletti and Scarpetta (2003): (i) competition creates opportunities for comparing performance, (ii) in a more competitive environment cost-reducing improvements in productivity can generate higher profits and revenues, (iii) managers will work harder not to lose market shares, and (iv) higher incentives to innovate.
} 
We use an unbalanced panel covering 30 countries over 15 years (1998-2013) and approximately 19,000 unique firms and 157,800 firm-year observations. Firm data have been collected from Compustat $\mathrm{S} \& \mathrm{P}$. As a measure of regulatory quality, we use the OECD product market regulation data including three sub-components: Barriers to entrepreneurship, state control and barriers to trade and investments. We find that the overall product market regulations do affect competition. In particular, we find that the impact of regulation on the long run permanent rents are robust with the exception of the sub-component barriers to entrepreneurship. We do not find any significant effect on short run persistence. Some caution is warranted when interpreting the results since 16 years might not be sufficiently long time period to fully capture profit dynamics. However, any profits that persist above the norm for any length of time suggest a systematic misallocation of resources. Our findings provide empirical evidence of the extent of indirect costs associated with product market regulations.

\section{Product market regulations and persistence of profits}

Entry of firms can be broadly characterized into two types. The first type of entry arises from imitative behavior, where firms enter to gain a share of the profits and innovation is not necessarily a crucial part of entry. Entry in the first case would suggest that with little or no entry, barriers to competition should return profits back to the normal levels. The second type of entry emerges from purely innovative actions and can be described more as Schumpeterian competition. In this case, innovation-driven entry induces (temporary) monopoly profits because they can, even in the extreme case, result in opening of completely new markets (see Mueller 2003 for discussion).

Therefore, above normal profits can persist in the short run. However, with little or no barriers to entry the above normal profits will be eroded through imitative or innovative competition. These two types of market entry indicate that above normal profits can emerge in the short run from either lack of competition or entrepreneurial monopoly rents, but profits should be reduced after some time in the absence of barriers to entry. If entry barriers do exist competition will be lower than optimal.

Product market regulations can potentially disrupt or impede product market competition. Regulations impose a cost to incumbents as well as potential entrants. If the cost of entry is too high, the market will exhibit a lower than optimal number of firms, i.e., too low competition. The regulations can have an impact on the productivity growth within a firm, on the productivity growth between firms due to the reallocation of resources or on the entry and exit of firms. ${ }^{7}$

\subsection{Persistence of profits}

Mueller (1977) suggests that profits $\left(\pi_{i t}\right)$ for firm $i$ at time $t$ can be decomposed into three components:

$$
\pi_{i t}=c+p_{i}+s_{i t}
$$

\footnotetext{
$\overline{7}$ See Haltiwanger (2000) and Ahn (2001) for a review of the different distributional levels.
} 
where $c$ is the competitive return common to all firms, $p_{i}$ is the permanent rent specific to firm $i$, and $s_{i t}$ is the firm-specific short run transitory rent at time $t$. The competitive return, $c$, is equal to profits in a fully competitive market. In case of presence of permanent rents, $p_{i}$ will be positive. The existence and magnitude of these permanent non-transitory rents as well as short run rents can be empirically examined using profit rates. $^{8}$

As mentioned, the persistence of profits literature goes back to the seminal contribution by Mueller $(1977,1986)$, where the convergence process of profits was examined for a sample of firms in the United States. After Mueller's contribution, multiple of studies have been made for individual economies, continuing with the United States by Waring (1996) among others but also for the United Kingdom, e.g. by Goddard and Wilson (1999), Japan by Odagiri and Yamawaki (1986) and for Turkey by Yurtoglu (2004). Some cross-country studies have also been introduced by Glen et al. (2001) for a sample of emerging economies, and Hirsch and Gschwandtner (2013) and Goddard et al. (2005) for a sample of European economies. However, to our knowledge, there are no studies of the impact of PMR on profit persistence.

The persistence of profits is commonly estimated as a first order autoregressive process:

$$
\pi_{i t}=\alpha_{i}+\lambda_{i} \pi_{i t-1}+\mu_{i t}
$$

where $\pi_{i t}$ is profits (measured as the demeaned return on assets), ${ }^{9} \pi_{i t-1}$ is the profit of the previous period and $\mu_{i t}$ is the conventional error term. The coefficient $\lambda_{i}$ measures the speed of adjustment, i.e., how fast the short run profits erode. The closer to zero the estimate is, the quicker short run rents erode and the less persistent profits are. Therefore, profits are dependent on their past values, typically with a mean reverting process. Research usually finds that short run profit persistence is 0.50 or less and that permanent rents tend to exist, with many firms with non-zero values of $p_{i}$.

\section{Data, variables and the empirical estimation}

We use an unbalanced panel with firm-level accounting data from Compustat Global Database combined with country-level indicators of product market regulations collected from the OECD Product Market Regulation Database. ${ }^{10}$ The data covers 30 countries across the time period of 1998-2013 on an annual frequency. There are close to 157,800 observations for 19,000 unique firms and the list of included countries is provided in "Appendix". The countries in the sample are selected so that we can have

\footnotetext{
8 Assuming that the short run rents dissipate over time according to $s_{i t}=\lambda s_{i t-1}+\mu_{i t}, 0 \leq \lambda<1$. Inserting this in Eq. 1 and rearranging, we obtain the following equation, which can be estimated empirically: $\pi_{i t}=\left(c+p_{i}\right)(1-\lambda)+\lambda \pi_{i t-1}+\mu_{i t}$. Note that the long run permanent profit $\left(c+p_{i}\right)$ can be estimated as $c+p_{i}=\alpha_{i} /\left(1-\lambda_{i}\right)$. See Mueller (2003) for details.

${ }^{9}$ Profits is measured as return on assets and demeaned: $\pi_{i t}=$ returnonassets $s_{i t}-$ $\sum_{i}^{N}$ returnonassets $s_{i t} / N$, where $\mathrm{N}$ is the number of firms at year $t$. This process removes cyclical components from profits common to all firms.

10 www.oecd.org/economy/pmr.
} 
a representation of countries within the OECD with both small and large economies with sufficient data coverage. The accounting data covers all listed companies in a given country.

Our dependent variable, profit, is measured as demeaned return on assets, which is the approach used in the literature. ${ }^{11}$ We add one lagged value of our dependent variable as an explanatory variable, as it measures the convergence of profits to the norm. As robustness check, we also incorporated up to three lags, but the results are robust (not reported).

As regulatory indicators we include product market regulation and its subcomponents; State Control, Barriers to Entrepreneurship and Barriers to Trade and Investment (see Wölfl et al. 2009, 2010). The underlying idea of the product market regulation (PMR) indicator is to turn qualitative data of laws and regulations and formal rules that can affect competition into a quantitative indicator (Wölfl et al. 2010). State control includes different measures of public ownership in a country or state's involvement in business operations. Heavy involvement of the state can create artificial barriers to entry or general misallocation of resources. Barriers to entrepreneurship include measures of the complexity of regulatory procedures and administrative burdens on start-ups, as well as regulatory protection of incumbents. If entrants find the cost of entering the market too high, both the cost of producing in addition to the cost of complying with regulations, the number of firms in an industry might stay at a too low of a level. Barriers to trade and investment incorporates explicit barriers to trade and investment and other barriers to trade and investment.

The data is based on surveys conducted by the OECD every fifth year (1998, 2003, 2008 and 2013). ${ }^{12}$ We interpolate the values between the survey years to be able to utilize a panel. ${ }^{13}$ The main idea behind the database is to proxy policy regimes and market conditions that are potentially anti-competitive. The variables are on a scale from 0 to 6 , with a higher number indicating more restrictive policies towards competition. See Wölfl et al. (2009) for details of the indicator and for more detailed description of the indicators and data collection methods can be obtained from Koske et al. (2015).

Further, we include a set of control variables that affect the profit dynamics of a firm at the firm and industry level. All the variables are obtained from the Compustat Global Database. The firm size is the taken as log of total net sales. In the presence of economies of scale, the relationship between firm size and profits will be positive. Previous empirical evidence seems to show that economies of scale can be found in some industries when not found in others (e.g. Yurtoglu 2004; Gschwandtner 2005) but nevertheless can potentially be important when measuring profitability. We add the variable market share, which is measured as firm's market share of industry sales

\footnotetext{
11 We trim the return on assets by the 1- and 99 percentiles to center our main variable since they are likely to be misreporting's or otherwise obscure outliers. We also exclude observations, which RoA is below -25 percent since these firms include those who receive loss coverage for some reason, i.e., R\&D firms do not always operate under regular profit motives, but receives continuous loss coverage.

12 There was an update on 2013 on the methodology of the indicator in terms of new questions. According to Koske et al. (2015) the correlation between the old ranking and the 2013 one is equal to 0.8. Our results are robust when excluding 2013. Also in 2008 there were some new methodological changes.

13 We used different variations of handling the data between the survey years, and the results are robust.
} 
Table 1 Summary statistics

\begin{tabular}{lllllll}
\hline & No. of Obs. & No. of Firms & Mean & Sd. Dev & Min & Max \\
\hline Profit & 157,771 & 19,262 & 0.607 & 6.83 & -28.0 & 26.8 \\
PMR & 157,771 & 19,262 & 1.61 & 0.365 & 0.910 & 2.71 \\
State control & 157,771 & 19,262 & 1.96 & 0.499 & 1.16 & 4.20 \\
$\begin{array}{l}\text { Barriers to } \\
\quad \text { entrepreneurship }\end{array}$ & 157,771 & 19,262 & 1.95 & 0.532 & 1.08 & 3.22 \\
$\begin{array}{l}\text { Barriers to trade } \\
\quad\end{array}$ & 157,771 & 19,262 & 0.913 & 0.435 & 0.120 & 2.44 \\
$\quad$ and investment & & & & & & \\
Firm size & 157,771 & 19,262 & 5.00 & 2.29 & -6.91 & 15.5 \\
Market share & 157,771 & 19,262 & 0.081 & 0.202 & 0.000 & 1.00 \\
Tangibles & 157,771 & 19,262 & 0.672 & 0.267 & -21.5 & 1.00 \\
Openness & 157,771 & 19,262 & 0.478 & 0.268 & 0.188 & 1.96 \\
TFP growth & 157,771 & 19,262 & 0.424 & 1.67 & -7.95 & 7.25 \\
\hline
\end{tabular}

at the 2-digit SIC level. The relationship between market share and profitability is often found to be positive (e.g. Shepherd 1972; Mullin et al. 1995), but if the market share is measuring diversification, the relationship can be negative (e.g. Lang and Stulz 1994). We also include firms' tangible assets (tangibles). Using the value of its physical assets as a share of total assets controls for firms' asset structure. This is done to test whether tangible assets can bring about higher profits. Conversely, Galbreath and Galvin (2008) emphasize that since tangible assets can be observed and imitated by rivals, they cannot be the source of permanent competitive advantage.

To control for country-level time-varying variables that might influence the persistence of profit, we add the openness of an economy and total factor productivity $(T P F)$ growth. In general, firms in an economy are prone to be influenced by nationwide changes, i.e., macro shocks, of both technology and trade. The openness of an economy is defined as the sum of exports and an import divided by total gross domestic product and is obtained from World Bank database. The amount of trade can affect domestic firms that do not compete in the international market themselves, but compete with open international markets. International firms can penetrate the domestic market and therefore increase competition. The openness of an economy can influence foremost the firms that are integrated in the foreign market. The TFP growth is obtained from the Conference Board Total Economy Database. It represents the technological changes an economy is experiencing. As firms adapt, they are influenced by not only the productivity of the surrounding environment, but also the productivity enhancements arising from technology.

Table 1 illustrates the whole data set. Detailed descriptive statistics for each country is provided in "Appendix". 
We estimate a first order autoregressive model that follows from Eq. 2. We add to the model a number of explanatory variables, including the interaction terms. Due to correlation between the regressors and the error terms the lagged dependent variable may cause biased and inconsistent estimates, when using OLS, fixed or random effect models. Even though the fixed effects estimation controls for the firm specific effects, it fails to capture correlation between the error term and the regressors imposed by the autoregressive process, so-called Nickell-bias still remains (Nickell 1981). To address this, we utilize a two-step generalized method of moments (GMM) estimator developed by Arellano and Bond (1991), or more commonly known as the difference GMM estimator. The method is designed for data with a large cross-section but with a short time series dimension and a lagged dependent variable as an explanatory variable. The firm-specific time invariant effects are removed by differencing transformation. Instruments are constructed within the dataset. The endogenous variables are instrumented by their lagged levels and the exogenous ones by themselves (Roodman 2009). Our model is described as:

$$
\pi_{i j t}=\lambda \pi_{i j t-1}+\alpha_{m} \mathbf{X}_{j t}+\delta_{m} \mathbf{X}_{m j t} * \pi_{i j t-1}+\gamma_{m} \mathbf{W}_{i j t}+\varepsilon_{i t}
$$

The subscripts denote firm $i$ in country $j$ at time $t$. We have profit $\left(\pi_{i j t}\right)$ as our dependent variable, and we add the lagged value of profit $\left(\pi_{i j t-1}\right)$ to represent the autoregressive process as described. $\mathbf{X}_{j t}$ is a vector of the regulatory variables in country $j$ at time $t$. The difference GMM does not produce the same type of long run persistence parameter as $\alpha$ captures in Eq. 2 . The estimated $\alpha_{m}$ 's can however be interpreted as indicating the direction of change in the long run profit persistence. We also add an interaction term between $\pi_{i j t-1}$ and our PMR indicators. This interaction term captures the effect of the regulation on the short run persistence of profit and thus the $\delta_{m}$ 's imply the change in the short run profit persistence arising from the regulatory variables.

By estimating a difference GMM, we are able to control for a set of observable covariates, as presented above and control for the unobserved time-invariant heterogeneity of firms while also correcting for the bias. We also apply different model specifications as robustness checks to validate our results.

\section{Results}

In Table 2 below, estimations of Eq. 3 are reported. The four different PMR-variables are added in separate estimations since they are highly correlated, as shown in the "Appendix Table 4".

We are interested in two effects on profits: (1) long run effects on permanent rents, which are captured by the PMR variables directly; (2) the persistence of profits in the short run, which is captured by the interaction terms. 
Table 2 Results with difference GMM

\begin{tabular}{|c|c|c|c|c|}
\hline Dependent variable: profit $\pi_{i t}$ & (1) & $(2)$ & (3) & (4) \\
\hline $\operatorname{Profit}_{\mathrm{t}-1}\left(\pi_{i t-1}\right)$ & $\begin{array}{l}0.213 * * \\
(0.0912)\end{array}$ & $\begin{array}{l}0.275 * * * \\
(0.0782)\end{array}$ & $\begin{array}{l}0.235^{* * * *} \\
(0.0813)\end{array}$ & $\begin{array}{l}0.231 * * * \\
(0.0332)\end{array}$ \\
\hline PMR & $\begin{array}{l}0.876 * * * \\
(0.230)\end{array}$ & & & \\
\hline State control & & $\begin{array}{l}0.795 * * * \\
(0.216)\end{array}$ & & \\
\hline Barriers to entrepreneurship & & & $\begin{array}{l}0.008 \\
(0.103)\end{array}$ & \\
\hline $\begin{array}{l}\text { Barriers to trade and } \\
\text { investment }\end{array}$ & & & & $\begin{array}{l}0.920 * * * \\
(0.234)\end{array}$ \\
\hline \multicolumn{5}{|c|}{ Interaction terms with profits $\left(\pi_{i t-1}\right)$} \\
\hline PMR & $\begin{array}{l}0.017 \\
(0.0568)\end{array}$ & & & \\
\hline State control & & $\begin{array}{l}-0.018 \\
(0.0396)\end{array}$ & & \\
\hline Barriers to entrepreneurship & & & $\begin{array}{l}0.004 \\
(0.0405)\end{array}$ & \\
\hline $\begin{array}{l}\text { Barriers to trade and } \\
\text { investment }\end{array}$ & & & & $\begin{array}{l}0.013 \\
(0.0365)\end{array}$ \\
\hline \multicolumn{5}{|c|}{ Firm and country level control variables } \\
\hline Firm size & $\begin{array}{l}-1.689^{* * *} \\
(0.426)\end{array}$ & $\begin{array}{l}-1.928^{* * *} \\
(0.434)\end{array}$ & $\begin{array}{l}-1.759 * * * \\
(0.422)\end{array}$ & $\begin{array}{l}-1.638^{* * *} \\
(0.430)\end{array}$ \\
\hline Market share & $\begin{array}{l}4.399 * * * \\
(0.584)\end{array}$ & $\begin{array}{l}4.614 * * * \\
(0.595)\end{array}$ & $\begin{array}{l}4.416^{* * * *} \\
(0.585)\end{array}$ & $\begin{array}{l}4.284 * * * \\
(0.578)\end{array}$ \\
\hline Tangibles & $\begin{array}{l}29.67 * * * \\
(4.760)\end{array}$ & $\begin{array}{l}29.37 * * * \\
(4.488)\end{array}$ & $\begin{array}{l}28.97 * * * \\
(4.580)\end{array}$ & $\begin{array}{l}28.95 * * * \\
(4.718)\end{array}$ \\
\hline Openness & $\begin{array}{l}1.064 \\
(0.859)\end{array}$ & $\begin{array}{l}0.681 \\
(0.863)\end{array}$ & $\begin{array}{l}0.974 \\
(0.852)\end{array}$ & $\begin{array}{l}1.286 \\
(0.859)\end{array}$ \\
\hline TFP growth & $\begin{array}{l}-0.009 \\
(0.019)\end{array}$ & $\begin{array}{l}-0.008 \\
(0.019)\end{array}$ & $\begin{array}{l}-0.007 \\
(0.019)\end{array}$ & $\begin{array}{l}-0.012 \\
(0.019)\end{array}$ \\
\hline Year FE & Yes & Yes & Yes & Yes \\
\hline Number of instruments & 29 & 29 & 29 & 29 \\
\hline No. of observations & 157,771 & 157,771 & 157,771 & 157,771 \\
\hline No. of firms & 19,262 & 19,262 & 19,262 & 19,262 \\
\hline $\begin{array}{l}\text { No. of countries } \\
\operatorname{AR}(2)\end{array}$ & 30 & 30 & 30 & 30 \\
\hline $\mathrm{z}$-value $[p$ value $]$ & $\begin{array}{l}-0.11 \\
{[0.914]}\end{array}$ & $\begin{array}{l}-0.14 \\
{[0.888]}\end{array}$ & $\begin{array}{l}-0.10 \\
{[0.921]}\end{array}$ & $\begin{array}{l}-0.05 \\
{[0.961]}\end{array}$ \\
\hline
\end{tabular}


Table 2 continued

\begin{tabular}{lllll}
\hline Dependent variable: profit $\pi_{i t}$ & $(1)$ & $(2)$ & $(3)$ & $(4)$ \\
\hline Hansen test of overriding restrictions & & & & \\
$\mathrm{X}^{2}[p$ value $]$ & 10.21 & 7.46 & 12.81 & 11.16 \\
& {$[0.116]$} & {$[0.280]$} & {$[0.046]$} & {$[0.084]$}
\end{tabular}

Windmeijer corrected standard errors in brackets. $* * *, * *$ and $*$ indicates significance at $1 \%, 5 \%$ and $10 \%$ respectively. Lagged dependent variable, interaction term and firm size treated as endogenous. Tangibles is treated as predetermined and all others as exogenous

Results show that the interaction terms between the PMR-variables and profit are statistically insignificant in all four cases. Thus, PMR does not seem to matter for the short run profit persistence. It can be the case that the regulatory setting is designed in a competitive manner in the short run, i.e., they do not hinder-or enhance- the convergence process of profits. Or product market regulations simply do not matter in the short run transitory rents. As mentioned, it may also be that the time series is not long enough to fully capture profit dynamics. However, the results show that the overall product market have a significant relationship with the long run profit levels. When looking at the sub-indicators, the results are statistically significant for all the indicators except for the domain barriers to entrepreneurship. The impact seems to be large in magnitude and the strongest impact is found for barriers to trade and investments. Thus, we conclude that the regulations mainly contribute to long run permanent rents.

As for the controls, we find a negative relationship between profits and firm size, which implies diseconomies of scale. We find a positive relationship between market share and profits suggesting a link between long run profits and monopoly/market power. Also, share of tangibles assets and profits are also found to have a positive relationship. However, the country-level covariates, openness and TFP growth do not have a significant effect on the long run profit persistence.

As a robustness check we also estimate a fixed effects estimator and also test for the impact of timing by lagging all our explanatory variables, The relevant results are reported in the "Appendix as Tables 5 and 6". We also estimate a hierarchical model-or so-called mixed effects model—where we can control for the different levels our data. These results are not reported. The results for the regulation variables are largely the same in particular with regard to the long run permanent rents. ${ }^{14}$

\section{Summary and policy implications}

This paper contributes to the existing literature by examining the relationship between product market regulations (PMR) and the profit persistence of firms by combining firm- and country-level information for a set of 30 OECD countries across 1998-2013. Despite a large literature on both regulations as well as profit persistence no other studies have to our knowledge attempted to link the two literatures together. Thus,

\footnotetext{
14 Further results can be obtained from the authors upon request.
} 
we advance the literature by: (1) examining the determinants of profit persistence, in particular the impact of PMR, (2) making use of both firm level information as well as cross-country variation.

We examine both the short run persistence of profits and the long run permanent rents. Our results show that product market regulations have no significant effect on the short run profit persistence. However, product market regulations significantly increase the long run permanent rents In addition to the overall PMR we also examine the effect of three subcomponents: barriers to trade and investments, state control and barriers to entrepreneurship. The domain barriers to entrepreneurship is the only indicator which does not have any significant effect on long run profits. The other subcomponents and the overall product market regulations are found to have a statistically and economically significant effect.

We conclude that product market regulations have a significant negative effect on long run competitiveness and are associated with a economically significant misallocation of resources. The findings are consistent with previous studies establishing a link between regulations and productivity growth. Regulators should be aware of the potential cost product market regulations impose on the competition of an economy, especially in regard to regulations arising from state control and trade and investment regulations. Our results have clear policy implications. Regulatory reforms that promote liberalization in product markets will decrease permanent rents and decrease the time needed for profits to converge to the norm. In other words, product regulations reduce competition.

Acknowledgements We gratefully acknowledge support from Marianne and Marcus Wallenberg foundation and Rune Andersson, Mellby Gård AB for research support. We are also grateful for valuable comments given by anonymous reviewer, Dennis C. Mueller, Björn Falkenhall and Pontus Braunerhjelm.

Open Access This article is distributed under the terms of the Creative Commons Attribution 4.0 International License (http://creativecommons.org/licenses/by/4.0/), which permits unrestricted use, distribution, and reproduction in any medium, provided you give appropriate credit to the original author(s) and the source, provide a link to the Creative Commons license, and indicate if changes were made.

\section{Appendix}

See Tables 3, 4, 5 and 6. 


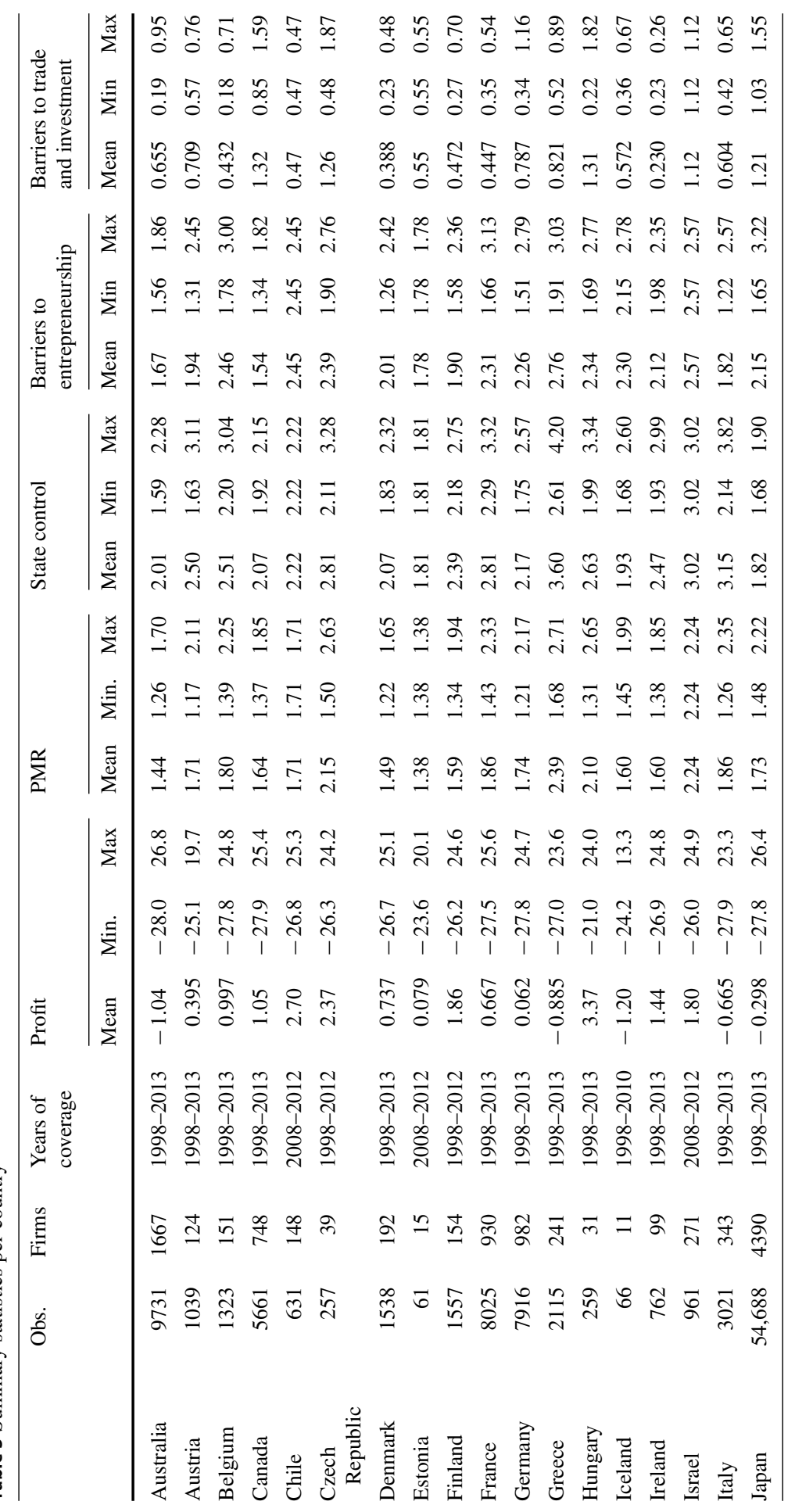




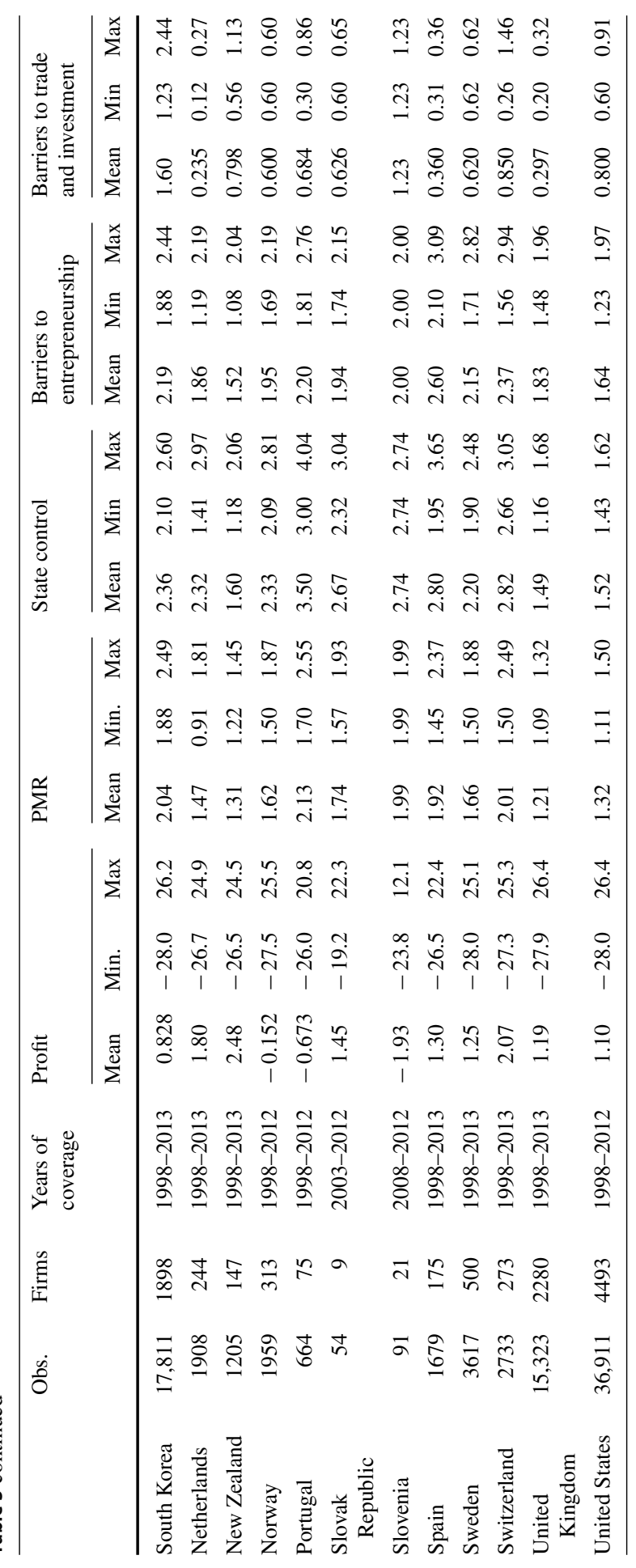




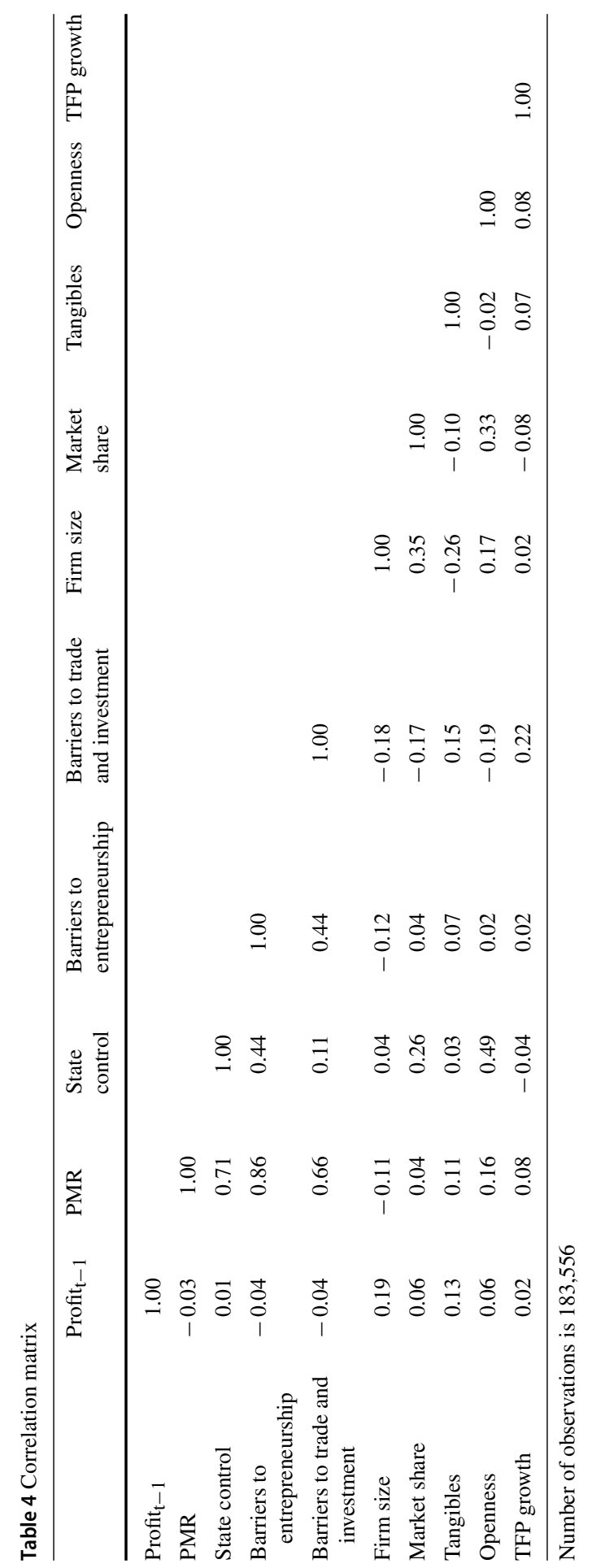


Table 5 Results with fixed effects estimator

\begin{tabular}{|c|c|c|c|c|}
\hline Dependent variable: profit $\pi_{i t}$ & (1) & (2) & (3) & (4) \\
\hline Constant & $\begin{array}{l}-10.4^{* * *} \\
(0.813)\end{array}$ & $\begin{array}{l}-10.6^{* * *} \\
(0.680)\end{array}$ & $\begin{array}{l}-9.56^{* * *} \\
(0.781)\end{array}$ & $\begin{array}{l}-12.1 \text { *** } \\
(0.850)\end{array}$ \\
\hline Profit $_{t-1}$ & $\begin{array}{l}0.134 * * * \\
(0.016)\end{array}$ & $\begin{array}{l}0.205^{* * *} \\
(0.015)\end{array}$ & $\begin{array}{l}0.134 * * * \\
(0.014)\end{array}$ & $\begin{array}{l}0.203 * * * \\
(0.009)\end{array}$ \\
\hline PMR & $\begin{array}{l}-0.052 \\
(0.146)\end{array}$ & & & \\
\hline State control & & $\begin{array}{l}0.089 \\
(0.115)\end{array}$ & & \\
\hline Barriers to entrepreneurship & & & $\begin{array}{l}-0.373^{* * * *} \\
(0.063)\end{array}$ & \\
\hline Barriers to trade and investment & & & & $\begin{array}{l}0.937 * * * \\
(0.129)\end{array}$ \\
\hline \multicolumn{5}{|c|}{ Interaction terms with profits $\left(\pi_{i t-1}\right)$} \\
\hline PMR & $\begin{array}{l}0.066^{* * *} \\
(0.010)\end{array}$ & & & \\
\hline State control & & $\begin{array}{l}0.017 * * \\
(0.007)\end{array}$ & & \\
\hline Barriers to entrepreneurship & & & $\begin{array}{l}0.053 * * * \\
(0.007)\end{array}$ & \\
\hline Barriers to trade and investment & & & & $\begin{array}{l}0.040 * * * \\
(0.008)\end{array}$ \\
\hline \multicolumn{5}{|c|}{ Firm and country level control variables } \\
\hline Firm size & $\begin{array}{l}1.37 * * * \\
(0.061)\end{array}$ & $\begin{array}{l}1.34 * * * \\
(0.062)\end{array}$ & $\begin{array}{l}1.39 * * * \\
(0.062)\end{array}$ & $\begin{array}{l}1.36 * * * \\
(0.062)\end{array}$ \\
\hline Market share & $\begin{array}{l}-0.917 * * \\
(0.317)\end{array}$ & $\begin{array}{l}-0.897 * * \\
(0.317)\end{array}$ & $\begin{array}{l}-0.942^{* *} \\
(0.317)\end{array}$ & $\begin{array}{l}-0.982 * * \\
(0.321)\end{array}$ \\
\hline Tangibles & $\begin{array}{l}8.63 * * * \\
(0.765)\end{array}$ & $\begin{array}{l}8.65 * * * \\
(0.770)\end{array}$ & $\begin{array}{l}8.60 * * * \\
(0.764)\end{array}$ & $\begin{array}{l}8.71 * * * \\
(0.775)\end{array}$ \\
\hline Openness & $\begin{array}{l}-2.11^{* * * *} \\
(0.326)\end{array}$ & $\begin{array}{l}-2.20^{* * * *} \\
(0.325)\end{array}$ & $\begin{array}{l}-2.35^{* * *} \\
(0.325)\end{array}$ & $\begin{array}{l}-1.00^{* * *} \\
(0.347)\end{array}$ \\
\hline TFP growth & $\begin{array}{l}0.069 * * * \\
(0.013)\end{array}$ & $\begin{array}{l}0.071 * * * \\
(0.013)\end{array}$ & $\begin{array}{l}0.057 * * * \\
(0.013)\end{array}$ & $\begin{array}{l}0.076 * * * \\
(0.013)\end{array}$ \\
\hline $\mathrm{R}^{2}$ & 0.22 & 0.22 & 0.22 & 0.22 \\
\hline No. of observations & 183,639 & 183,639 & 183,639 & 183,639 \\
\hline No. of firms & 20,994 & 20,994 & 20,994 & 20,994 \\
\hline No. of countries & 30 & 30 & 30 & 30 \\
\hline VIF & 3.55 & 3.12 & 3.47 & 2.10 \\
\hline
\end{tabular}

Firm and year fixed effects. Robust standard errors in brackets. ***, ** and * indicates significance at $1 \%$, $5 \%$ and $10 \%$ respectively 
Table 6 Results with lagged variables and fixed effects

\begin{tabular}{|c|c|c|c|c|}
\hline Dependent variable: profit $\pi_{i t}$ & (1) & (2) & (3) & (4) \\
\hline Constant & $\begin{array}{l}-0.506 \\
(0.420)\end{array}$ & $\begin{array}{l}-0.718 \\
(0.344)\end{array}$ & $\begin{array}{l}1.78 * * * \\
(0.326)\end{array}$ & $\begin{array}{l}-0.166 \\
(0.355)\end{array}$ \\
\hline Profit $_{t-1}$ & $\begin{array}{l}0.170 * * * \\
(0.017)\end{array}$ & $\begin{array}{l}0.232 * * * \\
(0.016)\end{array}$ & $\begin{array}{l}0.185 * * * \\
(0.015)\end{array}$ & $\begin{array}{l}0.231 * * * \\
(0.009)\end{array}$ \\
\hline $\mathrm{PMR}_{t-1}$ & $\begin{array}{l}0.324 * * \\
(0.149)\end{array}$ & & & \\
\hline State control $t-1$ & & $\begin{array}{l}0.305^{* * *} \\
(0.105)\end{array}$ & & \\
\hline Barriers to entrepreneurship $p_{t-1}$ & & & $\begin{array}{l}-0.205^{* * * *} \\
(0.063)\end{array}$ & \\
\hline $\begin{array}{l}\text { Barriers to trade and } \\
\text { investment }_{t-1}\end{array}$ & & & & $\begin{array}{l}0.774 * * * \\
(0.125)\end{array}$ \\
\hline \multicolumn{5}{|c|}{ Interaction terms with profits $\left(\pi_{i t-1}\right)$} \\
\hline $\mathrm{PMR}_{t-1}$ & $\begin{array}{l}0.062 * * * \\
(0.010)\end{array}$ & & & \\
\hline State control $t-1$ & & $\begin{array}{l}0.019 * * \\
(0.008)\end{array}$ & & \\
\hline Barriers to entrepreneurship $p_{t-1}$ & & & $\begin{array}{l}0.043 * * * \\
(0.007)\end{array}$ & \\
\hline $\begin{array}{l}\text { Barriers to trade and } \\
\text { investment }_{t-1}\end{array}$ & & & & $\begin{array}{l}0.042 * * * \\
(0.009)\end{array}$ \\
\hline \multicolumn{5}{|c|}{ Firm and country level control variables } \\
\hline Firm size $_{t-1}$ & $\begin{array}{l}-0.316^{* * * *} \\
(0.045)\end{array}$ & $\begin{array}{l}-0.333 * * * \\
(0.044)\end{array}$ & $\begin{array}{l}-0.296^{* * * *} \\
(0.045)\end{array}$ & $\begin{array}{l}-0.314 * * * \\
(0.044)\end{array}$ \\
\hline Market share $_{t-1}$ & $\begin{array}{l}-0.096 \\
(0.330)\end{array}$ & $\begin{array}{l}-0.053 \\
(0.331)\end{array}$ & $\begin{array}{l}-0.120 \\
(0.330)\end{array}$ & $\begin{array}{l}-0.179 \\
(0.336)\end{array}$ \\
\hline Tangibles $_{t-1}$ & $\begin{array}{l}1.61 * * * \\
(0.152)\end{array}$ & $\begin{array}{l}1.58 * * * \\
(0.152)\end{array}$ & $\begin{array}{l}1.58 * * * \\
(0.152)\end{array}$ & $\begin{array}{l}1.68 * * * \\
(0.153)\end{array}$ \\
\hline Openness $_{t-1}$ & $\begin{array}{l}-0.502 \\
(0.360)\end{array}$ & $\begin{array}{l}-0.853^{* *} \\
(0.360)\end{array}$ & $\begin{array}{l}-0.877 * * \\
(0.361)\end{array}$ & $\begin{array}{l}0.339 \\
(0.380)\end{array}$ \\
\hline TFP growth $_{t-1}$ & $\begin{array}{l}0.086 * * * \\
(0.014)\end{array}$ & $\begin{array}{l}0.085 * * * \\
(0.014)\end{array}$ & $\begin{array}{l}0.079 * * * \\
(0.014)\end{array}$ & $\begin{array}{l}0.089 * * * \\
(0.014)\end{array}$ \\
\hline $\mathrm{R}^{2}$ & 0.24 & 0.23 & 0.24 & 0.23 \\
\hline No. of observations & 172,081 & 172,081 & 172,081 & 172,081 \\
\hline No. of firms & 20,366 & 20,366 & 20,366 & 20,366 \\
\hline No. of countries & 30 & 30 & 30 & 30 \\
\hline
\end{tabular}

Firm and year fixed effects. Robust standard errors in brackets. $* * *, * *$ and $*$ indicate significance at $1 \%$, $5 \%$ and $10 \%$, respectively 


\section{References}

Ahn, S. (2001). Firm dynamics and productivity growth: A review of micro evidence from OECD countries. OECD economics department working papers no. 297.

Alesina, A., Ardagna, S., Nicoletti, G., \& Schiantarelli, F. (2005). Regulation and investment. Journal of the European Economic Association, 3(4), 791-825.

Amable, B., Demmou, L., \& Ledezma, I. (2009). Product market regulation, innovation, and distance to frontier. Industrial and Corporate Change, 42(1), 117-159.

Arellano, M., \& Bond, S. (1991). Some tests of specification for panel data: Monte Carlo evidence and an application to employment equations. The Review of Economic Studies, 58(2), 277-297.

Arnold, J. M., Nicoletti, G., \& Scarpetta, S. (2011). Regulation, resource reallocation and productivity growth. European Investment Bank Papers, 16(1), 90-115.

Bassanini, A., \& Duval, R. (2006). The determinants of unemployment across OECD countries: Reassessing the role of policies and institutions. OECD Economic Studies, 42(1), 7.

Blanchard, O., \& Giavazzi, F. (2003). Macroeconomic effects of regulation and deregulation in goods and labor markets. The Quarterly Journal of Economics, 118(3), 879-907.

Bouis, R., \& Duval, R. (2011). Raising potential growth after the crisis: A quantitative assessment of the potential gains from various structural reforms in the OECD area and beyond. OECD economics department working papers no. 835, OECD Publishing, Paris.

Bourlès, R., Cette, G., Lopez, J., Mairesse, J., \& Nicoletti, G. (2013). Do product market regulations in upstream sectors curb productivity growth? Panel data evidence for OECD countries. Review of Economics and Statistics, 95(5), 1750-1768.

Braunerhjelm, P., \& Eklund, J. E. (2014). Taxes, tax administrative burdens and new firm formation. Kyklos, 67(1), 1-11.

Cette, G., Lopez, J., \& Mairesse, J. (2016). Market regulations, prices, and productivity. American Economic Review, 106(5), 104-108.

Conway, P., De Rosa, D., Nicoletti, G., \& Steiner, F. (2006). Regulation, competition and productivity convergence. OECD economics department working papers no. 509.

Conway, P., Janod, V., \& Nicoletti, G. (2005). Product market regulation in OECD countries: 1998-2003. OECD economic department working papers no. 419, OECD Publishing, Paris.

Dawson, J. W. (2007). Regulation and the Macroeconomy. Kyklos, 60(1), 15-36.

de Soto, H. (1989). The other path: The invisible revolution in the third world. New York: Harper \& Row Publisher.

Djankov, S., La Porta, R., Lopez-de-Silanes, F., \& Shleifer, A. (2002). The regulation of entry. Quarterly Journal of Economics, 117(1), 1-37.

Escribá-Pérez, J., \& Murgui-García, M. J. (2016). Do market regulations reduce investment? Evidence from European regions. Regional Studies, 51(9), 1-12.

Feldmann, H. (2012). Product market regulation and labor market performance around the world. Labour, 26(3), 369-391.

Galbreath, J., \& Galvin, P. (2008). Firm factors, industry structure and performance variation: New empirical evidence to a classic debate. Journal of Business Research, 61(2), 109-117.

Geroski, P. A., \& Jacquemin, A. (1988). The persistence of profits: A European comparison. The Economic Journal, 98(391), 375-389.

Glen, J., Lee, K., \& Singh, A. (2001). Persistence of profitability and competition in emerging markets. Economics Letters, 72(2), 247-253.

Goddard, J., Tavakoli, M., \& Wilson, J. O. (2005). Determinants of profitability in European manufacturing and services: Evidence from a dynamic panel model. Applied Financial Economics, 15(18), 1269-1282.

Goddard, J. A., \& Wilson, J. O. (1999). The persistence of profit: A new empirical interpretation. International Journal of Industrial Organization, 17(5), 663-687.

Griffith, R., Harrison, R., \& Simpson, H. (2010). Product market reform and innovation in the EU. The Scandinavian Journal of Economics, 112(2), 389-415.

Gschwandtner, A. (2005). Profit persistence in the 'very'long run: Evidence from survivors and exiters. Applied Economics, 37(7), 793-806.

Haltiwanger, J. (2000). Aggregate growth: What have we learned from microeconomic evidence? Working Papers Organisation for Economic Cooperation and Development Eocnomics (Economics Department Working Papers No. 267). 
Hirsch, S., \& Gschwandtner, A. (2013). Profit persistence in the food industry: Evidence from five European countries. European Review of Agricultural Economics, 40(5), 741-759.

Kessing, S. G. (2006). Employment protection and product market competition. The Scandinavian Journal of Economics, 108(2), 339-352.

Klapper, L., Laeven, L., \& Rajan, R. (2006). Entry regulation as a barrier to entrepreneurship. Journal of Financial Economics, 82(3), 591-629.

Koske, I., Wanner, I., Bitetti, R., \& Barbiero, O. (2015). The 2013 update of the OECD's database on product market regulation. OECD economic department working papers no. 1200, OECD Publishing, Paris.

Lang, L. H. P., \& Stulz, R. M. (1994). Tobin's q, corporate diversification, and firm performance. Journal of Political Economy, 102(6), 1248-1280.

Lileeva, A., \& Trefler, D. (2010). Improved access to foreign markets raises plant-level productivity... for some plants. The Quarterly Journal of Economics, 125(3), 1051-1099.

Loayza, N., Oviedo, A. M., \& Servén, L. (2004), Regulation and macroeconomic performance. World bank policy research working paper (3469).

MacDonald, J. M. (1994). Does import competition force efficient production? The Review of Economics and Statistics, 76(4), 721-727.

Melitz, M. J., \& Ottaviano, G. I. P. (2008). Market size, trade, and productivity. The Review of Economic Studies, 75(1), 295-316.

Mueller, D. C. (1977). The persistence of profits above the norm. Economica, 44(176), 369-380.

Mueller, D. C. (1986). Profits in the long run. Cambridge: Cambridge University Press.

Mueller, D. C. (2003). The corporation. London: Routledge.

Mueller, D. C., \& Cubbin, J. (2005). The dynamics of company profits. Cambridge: Cambridge University Press.

Mullin, G. L., Mullin, J. C., \& Mullin, W. P. (1995). The competitive effects of mergers: Stock market evidence from the US Steel dissolution suit. The Rand Journal of Economics, 26(3), 314-330.

Nickell, S. (1981). Biases in dynamic models with fixed effects. Econometrica, 49(6), 1417-1426. https:// doi.org/10.2307/1911408.

Nicoletti, G., \& Scarpetta, S. (2003). Regulation, productivity and growth: OECD evidence. Economic Policy, 18(36), 9-72.

Odagiri, H., \& Yamawaki, H. (1986). A study of company profit-rate time series: Japan and the United States. International Journal of Industrial Organization, 4(1), 1-23.

Peltzman, S. (1976). Toward a more general theory of regulation. Cambridge, MA: National Bureau of Economic Research Cambridge.

Pigou, A. C. (1938). The economics of welfare. Basingstoke: Palgrave Macmillan.

Posner, R. A. (1974). Theories of economic regulation. Cambridge, MA: National Bureau of Economic Research Cambridge.

Roodman, David. (2009). A note on the theme of too many instruments*. Oxford Bulletin of Economics and Statistics, 71(1), 135-158. https://doi.org/10.1111/j.1468-0084.2008.00542.

Salvanes, K. G. (1997). Market rigidities and labour market flexibility: An international comparison. The Scandinavian Journal of Economics, 99(2), 315-333.

Schiantarelli, F. (2005). Product market regulation and macroeconomic performance: A review of cross country evidence. IZA discussion paper 1791.

Shepherd, W. G. (1972). The elements of market structure. The Review of Economics and Statistics, 54(1), 25-37.

Stigler, G. J. (1971). The theory of economic regulation. The Bell Journal of Economics and Management Science, 2, 3-21.

Waring, G. F. (1996). Industry differences in the persistence of firm-specific returns. The American Economic Review, 86(5), 1253-1265.

Wölfl, A., Wanner, I., Kozluk, T. J., \& Nicoletti, G. (2009) Ten years of product market reform in OECD countries-insights from a revised PMR indicator. OECD economics department working paper no. 695.

Wölfl, A., Wanner, I., Röhn, O., \& Nicoletti, G. (2010). Product market regulation: Extending the analysis beyond OECD countries. Economics department working paper no. 799; organization for economic co-operation and development economics department working paper no. 799.

Yurtoglu, B. B. (2004). Persistence of firm-level profitability in Turkey. Applied Economics, 36(6), 615-625. 